\title{
PENDIDIKAN KEMANDIRIAN BERBASIS KEWIRAUSAHAAN
}

\section{INDEPENDENCE EDUCATION BASED ON ENTREPRENEURSHIP EDUCATION}

\author{
RR Aliyyah ${ }^{1 a}$ dan S Rahmah ${ }^{2}$ \\ ${ }^{1}$ Program Studi Pendidikan Guru Sekolah Dasar, Fakultas Keguruan dan Ilmu Pendidikan, \\ Universitas Djuanda Bogor, Jl. Tol Ciawi No. 1 Kotak Pos 35 Ciawi Bogor 16720 \\ 2 Program Studi Manajemen Pendidikan Islam, Fakultas Keguruan dan Ilmu Pendidikan, \\ Universitas Djuanda Bogor, Jl. Tol Ciawi No. 1 Kotak Pos 35 Ciawi Bogor 16720 \\ a Korespondensi: Rusi Rusmiati Aliyyah, Email: rusi.rusmiati@unida.ac.id \\ (Diterima: 01-09-2017; Ditelaah: 02-09-2017; Disetujui: 14-10-2017)
}

\begin{abstract}
Independent Character Education has a purpose of confidence in carrying out an affair. This self-reliance education spurred the courage of someone in action, not resigned and frozen, but dynamic, energetic and always optimistic toward the future. Through Entrepreneurship it is a provision of santri or students in the future with the added value in the market, through the process of combining resources through different new ways, in order to compete. The purpose of this research is to describe the management function such as planning, implementation, supervision of self-reliance education, entrepreneurship of Darussyifa Al-Fithroh Sukabumi pesantren. The research used qualitative approach of case study. Data are collected through observation, interviews, documents, and recording / recording information. Data analysis techniques on research using Miles Huberman analysis model, the analysis component in the form of data reduction, data presentation, and conclusion or verification. The result of the research states that self-reliance education based on entrepreneurship planning is made by the team of pesantren, among them the leadership of pesantren, the chairman of the foundation, the heads, the teachers, the planning made the aspect of needs and interests, and determines the teachers who are capable in the implementation of the activities. The implementation of entrepreneurship based self-reliance education is done through the role model of all pesantren managers, conducted through habituation, assignment, implementation of entrepreneurial based self-reliance education included in Ta'aruf activities. The supervision of entrepreneurship based autonomy education is carried out by all board managers, supervision is given academically and managerially, and supervision through consultation meeting, coordination.
\end{abstract}

Keywords: education, independence, and entrepreneurship

\begin{abstract}
ABSTRAK
Penelitian ini bertujuan untuk mendeskripsikan fungsi manajemen diantaranya perencanaan, pelaksanaan, pengawasan pendidikan kemandirian dan kewirausahaan pondok pesantren. Penelitian menggunakan pendekatan kualitatif studi kasus. Data dikumpulkan melalui observasi, wawancara, dokumen, dan merekam informasi. Teknik analisis data menggunakan model analisis Miles Huberman melalui komponen analisis berupa reduksi data, penyajian data, serta kesimpulan atau verifikasi. Hasil penelitian menyatakan perencanaan pendidikan kemandirian berbasis kewirausahaa dibuat oleh tim penyelenggara diantaranya pimpinan pesantren, ketua umum yayasan, kepala sekolah, dan guru. Perencanaan dibuat berdasarkan analisis kebutuhan dan kepentingan organisasi. Pelaksanaan pendidikan kemandirian berbasis kewirausahaan dilakukan melalui suri tauladan dari seluruh pengelola pesantren, dilakukan melalui pembiasaan, penugasan, pelaksanaan pendidikan kemandirian berbasis
\end{abstract}


kewirausahaan termasuk dalam kegiatan Ta'aruf. Pengawasan pendidikan kemandirian berbasis kewirausahaan dilakukan oleh seluruh pengelola pesantren, pengawasan diberikan secara akademik dan manajerial, serta pengawasan melalui rapat konsultasi, dan koordinasi. Kata kunci: pendidikan, kemandirian, dan kewirausahaan.

Aliyyah RR dan S Rahmah. 2017. Pendidikan kemandirian berbasis kewirausahaan. Tadbir Muwahhid 1(2): 143-153.

\section{PENDAHULUAN}

Pendidikan Islam mengemban misi utama membentuk pribadi yang berkualitas yaitu manusia yang akan memiliki kemampuan dalam peningkatan potensi akhirnya mempunyai fungsi yang maksimal selaras dengan aturan yang ditentukan oleh Allah SWT dan Rasulullah SAW, sehingga akan terwujud manusia yang paripurna (Marzuki 2015).

Pendidikan Islam adalah proses terbentuknya kepribadian muslim. Isi kepribadian yang harusnya dimiliki seorang muslim itu sesungguhnya implementasi sepenuhnya ajaran Allah dan Rasul-nya. Pembinaan individu merupakan kewajiban, sebab itu menjadi pribadi muslim tidak akan mampu diwujudkan melainkan melalui pendidikan, maka pendidikan hal yang penting dan wajib dalam persfektif Islam (Daradjat 2012).

Pendidikan adalah usaha yang direncanakan pada pembimbingan serta pembelajaran untuk individu dalam proses pertumbuhan untuk memiliki kemandirian, rasa tanggung jawab, memiliki kreatifitas, memiliki ilmu pengetahuan, sehat jasmani serta rohani dan berakhlak mulia. Pendidikan nasional mempunyai satu misi yang tidak mudah, yaitu melahirkan manusia paripurna yang mempunyai nilainilai karakteristik yang baik selain itu mesti mempunyai keimanan serta ketaqwaan yang tanggung. Sebab itu, pendidikan adalah pilihan dalam perubahan untuk memiliki kemampuan dalam memperbaiki karakter bangsa.

Kemandirian adalah siapnya dan mampunya individu dalam berdiri sendiri yang memiliki ciri beraninya dalam pengambilan ide, berusaha mandiri dalam menyelesaikan masalah, berusaha menunjukkan sikap menuju kebaikan. Nabi Muhammad mengemban tugas suci yaitu terkandungnya doktrin-doktri kemandirian, amal shaleh, praktek, dan berusaha kerja keras. Doktri-doktrin yang dibawa beliau bukanlah mengajarkan untuk berpangku tangan, kebekuan kemandegan dan kepasrahan. Ajaran yang dilakukan beliau adalah doktrin yang menuntut adanya inisiatif, kreatifitas, inovasi, proaktif dan improvisasi serta reformatif.

Unsur kognitif untuk meraih kemandirian, sedangkan psikomotorik adalah tujuan untuk meraihnya. Sementara afektif merupakan pelumas dalam pelaksanaan psikomotorik tersebut. Sekali lagi demi tercapainya target untuk memulihkan keadaan bangsa yang dilanda keterpurukan multidemensi ini maka proses pendidikan sudah saatnya mengutamakan tujuan, yaitu psikomotorik. Hal ini tidak dapat diraih tanpa melalui pendidikan karakter mandiri (Sumahamijaya 2003).

Menteri ketenagakerjaan, M.Hanif Dhakiri yang dikutip Antara News (2016) memaparkan data pengangguran di Indonesia pada 2016 mendapat penilaian dengan titik yang rendah sejak 1998. Kementrian Ketenagakerjaan mencatat 
jumlah pengangguran pada 2016 mencapai 5,5 persen atau sekitar 7,02 juta juga lebih rendah dibanding 2015 yakni sebesar 5,18 yang setara 7,45 juta orang. Pencapaian yang dihasilkan atas usaha pemerintah dalam peningkatan kualitas SDM dikarenakan angkatan kerja Indonesia tergolong rendah kemampuannya. Data Sakernas BPS Februari 2016 mencatat angkatan kerja Indonesia dengan jumlah 127,67 juta jiwa dimana sekitar 60,38 persen merupakan lulusan SMP ke bawah. apalagi kalau dihitung dengan angkatan kerja berpendidikan hingga SMA persentasenya 77,81 persen.

Fakta diatas menunjukkan bahwa, pelaksanaan pendidikan di Indonesia belum terlihat adanya upaya yang optimal dalam mewujudkan cita-cita serta tujuan pendidikan nasional. Pemerintah memberikan solusi terhadap masyarakat untuk bagaimana caranya berwirausaha, oleh karenanya pendidikan kewirausahaan adalah salah satu program dari pemerintah khususnya Kementrian Pendidikan Nasional yang memiliki orientasi guna membangun serta mengembangkan individu memiliki kreatifitas, inovatif, sportif serta wirausaha, selaras dengan tujuan pendidikan nasional. Pendidikan kewirausahaan ini dikaitkan dengan program lain, seperti pendidikan karakter, ekonomi, serta kewirausahaan.

Pendidikan kemandirian berbasis kewirausahaan ini menjadi lanjutan dari penelitian dengan judul penyelenggaraan pendidikan berbasis karakter dan teknologi dalam mengatasi tantangan globalisasi (RR Aliyyah. 2014: JSH ISSN 2087-4928 Volume 5 Nomor 1) yang menyatakan bahwa penyusunan perencanaan dibuat melalui rapat dan pembinaan antara stakeholder pendidikan, sedangkan pengawasan kepada siswa dilakukan melalui diberdayakannya Buku Kejar Prestasi (BKP) dan Sistem Informasi Manajemen (SIMAK).
Peneliti melakukan penelitian di pondok pesantren dengan maksud menemukan strategi lain dalam hal perencanaan, pelaksanaan serta pengawasan pendidikan yang tidak sama dengan penelitian terdahulu. Pembeda satuan pendidikan formal serta non formal menjadi hal unik untuk peneliti dapatkan hasilnya sehingga penelitian mampu memberikan gambaran pada awalnya baik pada jenjang pendidikan formal serta non formal senantiasa memiliki strategi dalam pengelolaan lembaga pendidikannya. SMK dan pondok pesantren harus senantiasa berjalan beriringan karena memiliki peran serta fungsi yang signifikan pada tahapan proses pendidikan masyarakat pada umumnya, dimana masyarakat akan mendapatkan ilmu secara teoritis dari pendidikan formal dan menerima pengalaman secara terstruktur dari pendidikan non formal.

Pondok Pesantren merupakan salah satu solusi bagi pemerintah untuk membentuk karakter mandiri, membentuk karakter manusia yang bisa berwirausaha. Pesantren Darussyifa Al-Fithroh adalah salah satu lembaga pendidikan pesantren didalamnya mengajarkan pentingnya pendidikan kemandirian berbasis kewirausahaan. Santri tidak hanya diajarkan baca tulis Al-qur'an dan kajian kitab kuning tetapi dibekali pengatahuan mengenai pertanian, peternakan, perikanan, koperasi dan air minum dalam kemasan (AMDK).

Dengan kegiatan kewirausahaan itulah salah satu bentuk pendidikan kemandirian yang diajarkan oleh pengelola pesantren Darussyifa Al-fithroh dalam memenuhi kebutuhan dan pendidikan para santri. 


\section{MATERI DAN METODE}

\section{Materi}

\section{Pendidikan Kemandirian berbasis Kewirausahaan}

Pendidikan merupakan sejumlah pengalaman dari seseorang atau kelompok untuk dapat memahami sesuatu yang sebelumnya tidak mereka pahami. Pendidikan merupakan proses perkembangan serta pengembangan manusia, diantaranya usaha yang dilakukan dalam penanaman juga pengembangan nilainilai pendidikan, yang menjadi bagian kepribadian anak didik yang pada akhirnya anak didik memiliki kepandaian, kebaikan, kemampuan menjalani hidup serta berguna untuk masyarakat (Nata 2003).

Kemandirian merupakan kesiapan juga kemampuan individu untuk mandiri, memiliki keberanian dalam pengambilan inisiatif, berusaha menghadapi masalah dengan mandiri, berusaha menunjukkan tingkah laku menuju kesempurnaan. Kemandirian merupakan komponen terpenting dari moralitas yang berasal dari lingkungan masyarakat. Pertumbuhan dan perkembangan kemandirian karena dua faktor, yaitu kedisiplinan dan komitmen terhadap kelompok, sebab itu individu mandiri adalah individu yang berani mengambil keputusan berdasarkan pemahaman akan segala konsekuensi dari tindakannya. Kemandirian diperoleh melalui proses realisasi kedirian dan proses menuju kesempurnaan (Muhtadi 2015)

Kemandirian termasuk kemampuan berinisiatif, menghadapi segala rintangan juga masalah, percaya diri yang tinggi serta melakukan sesuatu sendiri tanpa bantuan orang lain. Kemandirian juga merupakan keinginan melakukan segala sesuatu untuk diri sendiri. Artinya bahwa kemandirian merupakan keadaan seseorang yang mempunyai keinginan bersaing untuk maju demi kebaikan dirinya, dapat mengambil keputusan serta inisiatif dalam mengatasi masalah yang dihadapi, percaya diri dalam mengerjakan tugas-tugasnya serta bertanggung jawab atas apa yang dilakukan.

Pendidikan Karakter Mandiri memiliki orientasi dalam membentuk individu yang percaya terhadap dirinya sendiri dalam menghadapi suatu urusan. Karakter mandiri ini memacu dan mendorong seseorang dalam menyelesaikan sendiri persoalan yang dihadapinya, sehingga memiliki motivasi berinisiatif, berkreasi, berinovasi, proaktif serta bekerja keras. Pendidikan budi pekerti mandiri ini mendorong munculnya keberanian dalam berbuat atau beraksi, tidak pasrah dan beku, tetapi dinamis, energik serta selalu optimis menuju masa depan (Sumahamijaya 2003).

Kewirausahaan merupakan terciptanya nilai tambah di pasar, melewati proses pengkombinasian sumber daya menggunakan cara-cara baru juga berbeda, agar dapat bersaing. Kewirausahaan juga merupakan proses terciptanya sesuatu nilai baru, memakai waktu serta upaya, menanggung resiko keuangan, fisik serta sosial yang mengiringi, namun ada resiko moneter serta kepuasaan juga kebebasan pribadi (Usman 2013)

Kewirausahaan diartikan juga sebagai kemampuan melihat juga menilai peluang bisnis, mengumpulkan sumber daya yang dapat digunakan untuk mengambil keuntungan dan mengambil tindakan yang efektif dalam mencapai sebuah kesuksesan (Daryanto 2012).

Dalam perspektif Islam, karakter atau akhlak mulia adalah buah hasil penerapan syariah (ibadah dan muamalah), dilandasi oleh fondasi akidah kokoh. Ibarat suatu bangunan, karakter atau akhlak adalah 
sempurnanya bangunan sesudah kuatnya fondasi dan bangunan. Artinya, tidak mungkin karakter mulia terwujud dalam diri individu seandainya tidak mempunyai akidah atau iman yang benar, terlihat dari implementasi perilaku sehari-hari yang didasari imannya. Pentingnya karakter mulia (akhlak karimah) dipertegas oleh Nabi Muhammad SAW dengan pernyataan yang menselaraskan akhlak serta kualitas keinginan, jumlah amal, serta jaminan masuk surga. Karakter sesuai paradigma islam tidak saja hasil dari proses berpikir dan tidak juga terlepas dari kenyataan kehidupan, yaitu persoalan yang menyangkut sesuai akal, ruh, hati, jiwa, kenyataan serta orientasi yang ditentukan oleh perilaku Qur'aniah. Oleh sebab itu, karakter mulia adalah satu kesatuan perilaku yang diutamakan agama Islam yang tertuang dalam nash Al-Quran dan hadits (Marzuki 2015).

Islam memiliki pandangan bahwa sikap mandiri merupakan sikap yang tidak akan dilepaskan dari tugas manusia, yakni merealisasikan misinya sebagai hamba Allah dan khalifah dimuka bumi ini. Secara eksplisit, Islam tidak menjelaskan terkait tentang kewirausahaan. Namun, Islam memiliki pandangan bahwa bekerja serta berusaha adalah sebuah konsep dari kewirausahaan. Yang merupakan tugas khalifah Allah dalam mengurus dan memlihara alam semesta ini. Lebih jelas lagi Allah memerintahkan supaya manusia itu berusaha mencari bekal untuk akhirat (beribadah), tanpa melupakan hidup didunia ini, dan dilarang berbuat kerusakan.

\section{Metode}

Pendekatan yang digunakan adalah pendekatan kualitatif, dengan metode studi kasus. Pendekatan kualitatif dengan metode studi kasus digunakan untuk mengkaji dan menjawab permasalah serta untuk memperoleh makna yang lebih mendalam mengenai pendidikan kemandirian dan kewirausahaan. Data penelitian dibedakan berupa data kata-kata, tindakan, data tertulis, dan foto. Sehingga data utama pada yang digunakan adalah data berupa katakata dan tindakan, sedangkan untuk data berupa dokumen tertulis dan foto digunakan sebagai data tambahan (Moleong 2008).

Teknik observasi, wawancara, dan dokumen digunakan dalam penelitian untuk mengambil data. Teknik observasi yang dipilih berupa observasi partisipan, sedangkan wawancara menggunakan semi terstuktur. Dokumen yang digunakan diambil darilingkungan alamiah sebagai sumber data langsung, yaitu berupa mekanisme pengelolaan pesantren dan fotofoto kegiatan santri.Lingkungan alamiah yang dimaksud berlokasi diPondok Pesantren Darussyifa Al-fithroh (Yaspida) Sukabumi, yang beralamat di Jalan Parungseah No. 43 Km 04 Desa Cipetir Kecamatan Kadudampit, Kabupaten Sukabumi. Peneliti mengamati, mencatat, bertanya, dan menggunakan alat bantu perekam dalam mendapatkan data yang ada kaitannya dengan peristiwa yang terjadi.

Pengumpulan data penelitian ini terbagi menjadi dua bagian yaitu sumber data primer dan skunder. Sumber data primermencakup segala elemen yang menyangkut Pesantren Darussyifa Al-fitroh (Yaspida Sukabumi), seperti pimpinan pesantren, ketua umum yayasan, sekretaris umum yayasan, pembina pesantren, kepala kepesantrenan, asatidz wal asatidzah, serta santri. Semua elemen tersebut terlibat langsung dalam perencanaan, pelaksanaan, sekaligus pengawasan kegiatan pendidikan yang menekankan pada kemandirian dan berbasis kewirausahaan.Sumber data sekunder atau penunjang berupabahan tertulis berbentuk dokumen-dokumen 
seperti buku panduan, profil pondok pesantren, koran, dan sebagainya yang didapat dari Pondok Pesantren Salafiyyah Darussyifa Al-fitroh (Yaspida) Sukabumi.

Sedangkan teknik analisa data penelitian menggunakan tahapan yang diberlakukan pada data sebagaimana yang dikemukakan Miles dan Huberman, yaitu tahap reduksi, penyajian, dan penarikan kesimpulan atau verifikasi. Sedangkan untuk pemeriksaan keabsahan data dilakukan melalui kredibilitas, transferabilitas, dependabilitas, dan konfirmabilitas (Miles dkk 1992).

\section{HASIL DAN PEMBAHASAN}

\section{Hasil}

Data atau informasi yang akan di paparkan di bawah ini merupakan hasil temuan penelitian yang didapatkan melalui proses observasi, pengamatan dan wawancara kepada orang-orang yang ada di Pondok Pesantren Darussyifa Al-fithroh yakni Pimpinan Pondok Pesantren, Ketua Umum Yayasan, Sekretaris Umum Yayasan, Kepala Kepesantrenan, Pembina Pesantren, Asatidz unit usaha, dan Santri.

\section{Perencanaan Pendidikan Kemandirian Berbasis Kewirausahaan}

a. Penyusunan pendidikan kemandirian berbasis kewirausahaan di pondok pesantren di buat oleh Tim penyelenggara yaitu pimpinan pondok pesantren, ketua umum yayasan dan sekretaris umum yayasan, para kepala, asatidz, dan sebagainya. ini dilakukan untuk mengakomodir saran dan pendapat juga kebutuhan pada saat melaksanakan rencana program tersebut. Prosedur dalam menetapkan program tersebut harus selaras dengan tujuan, maka program dilakukan melalui rapat. Sebelumnya pimpinan pondok mempunyai keinginan dengan melihatnya fasilitas dan potensi para santri. Akhirnya ide untuk membuat program pendidikan kemandiran itulah disampaikan kepada sekretaris umum yayasan dan Pembina kepesantrenan agar dapat diikuti semua pengelola pesantren. Tujuannya agar seluruh pengelola pesantren tahu dan memahami akan program dan perkembangan pesantrennya serta dapat memberikan usulan, yang bertujuan untuk mendapatkan kesepakatan bersama sehingga disepakati oleh Pimpinan Pondok.

b. Dengan demikian rapat merupakan sesuatu yang senantiasa dilakukan oleh Pondok Pesantren Darussyifa Al-fithroh dalam upaya merencakan sebuah program.

c. Perencanaan pendidikan kemandirian berbasis kewirausahaan di Pondok Pesantren Darussyifa Al-fithroh dilakukan karena adanya aspek kebutuhan dan aspek kepentingan. Berdasarkan hasil wawancara, dalam pendidikan kemandirian berbasis kewirausahan ini karena adanya aspek kebutuhan, kepentingan (Need \& Interest) dan penciptaan lingkungan yang dilakukan guna melaksanakan pendidikan kemandirian berbasis kewirausahaan di lingkungan pondok pesantren yang lingkungannya harus terisolasi jangan digabung dengan masyarakat luas, tapi harus di sentralisasikan jangan sampai nanti santri terkontaminasi dengan masyarakat luas. Hal tersebutlah yang mendasari pihak pengelola pesantren dalam melaksanakan pendidikan kemandirian berbasis kewirausahaan. 
d. Dalam menetapkan program, pimpinan pesantren menentukan atau menunjuk asatidz untuk memiliki tanggung jawab penuh dalam pelaksanaannya ketika dilapangan, bertujuannya agar kegiatan santri ini lebih terorgansir, terarah dan terpantau.

e. Perencanaan pendidikan kemandirian berbasis kewirausahaan karena adanya tujuan untuk para santri. Dengan adanya pendidikan kemandirian bebasis kewirausahaan ini pengelola pesantren memiliki tujuan untuk para santrinya dimasa depan. Dengan demikian tujuan dibuatnya pendidikan kemandirian berbasis kewirausahaan yaitu mempersiapkan kader bangsa yang produktif, siap pakai, tidak menjadikan beban untuk berlangsungnya kehidupan masyarakat lain. kemandirian dalam bersikap, bertindak, berfikir, dan berkarya nyata.

\section{Pelaksanaan Pendidikan Kemandirian Berbasis Kewirausahaan}

a. Pelaksanaan Pendidikan Kemandirian Berbasis Kewirausahaan dilaksanakan dengan metode suri tauladan juga contoh yang baik dimulai dari Pimpinan pondok, asatidzh, pengasuh (pengabdian/karyawan) dan para santri. Sehingga santri dapat terarah, terbimbing dan terpantau dalam pelatihan pendidikan kemandirian dan kewirausahaan tersebut. Menurut informasi hasil observasi serta wawancara bersama sesepuh pondok, para guru terkait bentuk pelaksanaan pendidikan kemandirian berbasis kewirausahaan pada Pondok pesantren Darussyifa Al-fithroh ini, melalui suri tauladan, pengarahan, pembiasaan dan penugasan. Suri tauladan adalah proses yang baik pada terlaksananya pendidikan serta pengajaran. Agar santri atau siswa yang dilatih dapat memahami proses yang dilakukan.

b. Pelaksanaan pendidikan kemandirian berbasis kewirausahaan dilaksanakan dengan metode pembiasaan serta penugasan. Berdasarkan observasi serta wawancara, setiap hari setelah melakukan tugas kewajiban untuk mengaji, berjamaah dan sekolah. Santri pun di didik untuk peduli lingkungan sekitarnya, melaksanakan qiyamullail, shalat duha dan tadarus terlebih dahulu sebelum melaksanakan pembelajaran disekolah. Dalam penugasan pendidikan kemandirian berbasis kewirausahaan, semua santri dilibatkan dan diberi tanggung jawab pada beberapa proses pendidikan kegiatan kewirausahaan. Melalui bermacam-macam pelatihan yang dilakukan santri menjadikan bekal dan kepahaman untuk masa depan.

c. Pelaksanaan Pendidikan Kemandirian berbasis kewirausahaan melalui kegiatan Ta'aruf yang dilaksanakan untuk semua santri baru guna membentuk karakter santri. Melalui dokumentasi serta wawancara, kegiatan ta'aruf merupakan bentuk pelaksanaan yang setiap tahun dilakukan santri baru ketika masuk ke dalam pondok Pesantren Darussyifa Alfitroh, bertujuannya santri dapat beradaptasi lebih mudah dengan lingkungan baru yang dihadapinya. Melalui kegiatan ta'aruf itulah langkah awal yang dilaksanakan oleh Pondok Pesantren Darussyifa Alfithroh guna santri betah dengan lingkungan barunya, yang diajarkannya bukan hanya dalam kegiatan keagamaan saja, namun dilaksanakan aktivitas kewirausahaan yang terdapat dilingkungan pondok pesantren tersebut. 


\section{Pengawasan Pendidikan Kemandirian Berbasis kewirausahaan}

a. Seluruh pengelola pesantren terlibat melakukan pengawasan pendidikan kemandirian berbasis kewirausahaan. Sekalipun dalam proses kewirausahaan telah ditetapkan para asatidz memiliki tanggung jawab penuh dalam kegiatan itu, tapi pimpinan pondok menyarankan seluruh pengelola terlibat pengawasan, tujuannya agar semua santri merasa terawasi dan kita semua merasa memiliki dengan asset lembaga yang ada. Pelaksanaan pengawasan dilaksanakan seluruh pengelola pesantren guna dapat terpantaunya para santri dalam pelaksanaan pendidikan.

b. Pengawasan pendidikan kemandirian berbasis kewirausahaan diberikan secara akademik dan manajerial. Setelah melakukan perencanaan serta pelaksanaan proses pendidikan kemandirian berbasis kewirausahaan oleh santri. Berdasarkan hasil observasi serta diskusi dengan beberapa informan, peneliti mengetahui bahwa sistem pengawasan pendidikan kemandirian berbasis kewirausahaan di Pondok Pesantren Darussyifa Al-fithroh (Yaspida) Sukabumi dilakukan melalui pengawasan secara akademik serta manajerial. Pengawasan akademik dilakukan dengan cara melaksanakan pengawasan aspek $5 \mathrm{P}$, pemantauan, dan pelatihan materi pada santri. Pengawasan secara non akademik (manajerial) diberikan guru dijadikan sebagai fasilitator semua santri, guna membantu mereka dalam hal pembelajaran dan hasil kerja para santri.

c. Pengawasan pendidikan kemandirian berbasis kewirausahaan melalui rapat konsultasi serta koordinasi. Pengawasan dilaksanakan seluruh pihak pengelola pesantren termasuk pihak yayasan pun selalu terlibat melakukan pemantauan perkembangan aktivitas yang direncanakan, dilaksanakan dalam beberapa hari, beberapa minggu, pihak yayasanpun selalu mengadakan rapat konsultasi dan koordinasi. Rapat koordinasi yaitu rapat umum. Pengurus struktural pesantren yaitu top management, midle management, serta low management untuk melakukan penilaian berjalan atau tidaknya organisasi serta memberikan solusi atas masalah-masalah yang muncul pada setiap minggu terakhir. Rapat dilaksanakan setiap hari kamis, yang dipimpin Dewan Keorganisasian. Dan rapat konsultasi yaitu rapat yang disaksikan seluruh steackholder pendidikan dalam semua komponen yang ada, rapat yang selalu dilaksanakan pada satu bulan sekali pada tanggal 7 . Dengan berbagai bentuk pengawasan yang dilaksanakan pihak pondok pesantren guna mengetahui maju atau tidaknya suatu program yang telah direncanakan dan dilaksanakan.

\section{Pembahasan}

Berdasarkan temuan selama pengambilan data, perencanaan pendidikan kemandirian berbasis kewirausahaan di Pondok Pesantren Darussyifa Al-fithroh. Dalam merencanakan sebuah program pendidikan, seluruh tim pengelola pesantren (stakeholders pendidikan) berhak untuk mengemukakan pendapat ataupun memberikan aspirasi dalam forum rapat tentang program selanjutnya yang akan dilaksanakan. Hal ini adalah sebuah pengejewantahan pada sebuah konsep otonomi pendidikan dimana setiap masyarakat pesantren berhak memberikan pendapatnya dalam berbagai kesempatan. 
Karena hanya dengan ide brilian dari seluruh warga pesantren tersebut akan menjadi lebih baik pada berbagai programnya. Berkaitan dengan dilakukannya rapat guna pencapaian tujuan dan mengumpulan saran serta inspirasi semua guru. Perencanaan yaitu proses memilih dalam mencari dan memilih tujuan yang tepat dan arah tindakan. Tiga langkah pada tahap perencanaan adalah : 1) memutuskan tujuan organisasi, 2)memutuskan apa program tindakan untuk mengadopsi tercapainya tujuan tersebut, dan 3) memutuskan pengalokasian sumberdaya organisasi dalam pencapaian sebuah tujuan.Terkait dengan kemampuan untuk membuat perencanaan (plans) yang baik, maka perencanaan harus senantiasa di musyawarahkan pada team kerja. Agar kemudian, konsep perencanaan tersebut mendekati sempurna setelah dilakukan komunikasi atau koordinasi dengan team. Tanpa disadari proses pembuatan perencanaan yang dilaksanakan oleh Pondok Pesantren Darussyifa Al-fithroh sebenarnya mengadopsi pendapatnya Robins dan Coulter. Perencanaan adalah fungsi manajemen yang melibatkan tujuan mendefinisikan, strategi membangun untuk mencapai tujuan, dan menumbuhkan perkembangan untuk mengintegrasikan dan mengkoordinasikan kegiatan.

Setelah perencanaan pendidikan kemandirian berbasis kewirausahaan telah ditetapkan salah satu upaya pelaksanaan tersebut melalui pemberian suri tauladan dan pembiasaan yang baik dari setiap guru, pimpinan pondok dan pengasuh Pondok Pesantren Darussyifa Al-fithroh kepada santri pun terlibat pelaksanaannya. Sebelum para santri melaksanakan pengajian, biasanya mereka akan berdo'a dan membaca asmaul husna terlebih dahulu. Dan setelah melaksanakan pengajian para santri wajib untuk membersihkan lingkungan sekitar, sesudah itu para santri sebelum memulai KBM disekolah para santri, guru serta seluruh pengelola pesantren terlibat dalam pelaksanaan shalat duha bersama. Setelah adzan dzuhur berkumandang, maka berduyun-duyun para siswa/santri dan guru untuk melaksanakan shalat berjamaah.

Diantara yang membedakan Pondok Pesantren Darussyifa Alfitroh dengan pesantren lain karena proses pendidikan kemandirian yang dilakukan bukan hanya saja dalam kegiatan harian santri dipondok melaui mengaji, shalat berjamaah membersihkan lingkungan melainkan santripun di didik untuk belajar kewirausahaan. Dimana pembiasaan dan pemberian suri tauladan santri pada implementasinya pendidikan kemandirian berbasis kewirausahaan ini para asatidz ikut serta dilapangan guna untuk mengarahkan dan membimbing para santri dalam pelaksanaan kemandirian berbasis kewirausahaan tersebut. Jika dilihat dalam proses pelaksanaan oleh para asatidz yang memberikan contoh kepada santrinya.

Hal terakhir yang dilakukan setelah pihak pesantren membuat perencanaan serta pelaksanaan adalah upaya pengawasan atau pengendalian untuk melihat dan mengontrol sejauh mana perencanaan dan pelaksanaan program tersebut tercapai.

$\begin{array}{ccr}\text { Bentuk } & \text { pengawasan } & \text { akademik } \\ \text { pendidikan } & \text { kemandirian } & \text { berbasis }\end{array}$ kewirausahaan dengan cara melaksanakan pengawasan dengan aspek 5P, pemantauan, dan pelatihan materi kewirausahaan pada santri. Aspek 5P misalnya Pembinaan mental, karakter, dan nilai-nilai pendidikan yang tersimpan didalamnya langsung diarahkan oleh pimpinan pesantren. Secara rutin, pimpinan pesantren menyampaikan nasihat dan wejangan untuk semua santri agar menjadi muslim/muslimah yang berkarakter baik. Aspek Pemantauan, 
pemantauan dengan tiga cara yang pertama adalah pemantaun secara menyeluruh, dimulai dari dia bangun, bagaimana aktiv belajar, bagaimana aktivitas kegiatan seharihari, bagaimana kegiatan dalam berakhlak, bergaul dan bersikap, yang kedua secara administrasinya, yang didapat dari hasil pembelajaran, evaluasi pembelajaran, dan penerapan kurikulum terhadap pada santri tersebut berhasil atau tidak. Sedangkan untuk pengawasan manajerial dilakukan dengan cara guru menjadi fasilitator pada pembelajaran, pengawas yang mengidentifikasi kemampuan dan kekurangan anak, informan pengembangan diri santri dan evaluator terhadap hasil kerja anak.

\section{KESIMPULAN DAN IMPLIKASI}

\section{Kesimpulan}

Perencanaan pendidikan kemandirian berbasis kewirausahaan terdiri dari penyusunan perencanaanyang menekankan pada kemandirian dan berbasis kewirausahaan yang terjadi di lingkungan Pesantren Darussyifa Al-fithroh (Yaspida) Sukabumi. Perencanaan tersebut dibuat karena aspek kebutuhan dan kepentingan oleh Tim Penyelenggara melalui rapat dan pembinaan oleh seluruh pengelola pesantren.Tujuan dari pendidikan berbasis kemandirian menghasilkan lulusan-lulusan yang siap menghadapi tantangan, handal, dan tidak tergantung pada masyarakat lain. Pelaksanaan kegiatan pendidikan yang menekankan pada kemandirian dan berbasis kewirausahaan di Pesantren Darussyifa Alfithroh dilakukan melalui pelaksanaan ta'arufoleh santri-santri baru guna membentuk karakter santri-santri.

Pelaksanaan pendidikan kemandirian berbasis kewirausahaandilakukan melalui bentuk kegiatan pembiasaan dan penugasan. Kegiatan pembiasaan selalu dilakukan seluruh stakeholderPesantren Darussyifa Alfithroh. Kegiatan dilakukan melalui pemberian suri tauladan dari pimpinan pondok, pembina kepesantrenan, kepala kepesantrenan, guru, dan santri.

Pengawasan dilakukan secara akademik dan manajerial. Pengawasan pendidikan kemandirian yang berbasis kewirausahaan menjadi tanggung jawab pimpinan pondok, sedangkan seluruh pengelola pesantren wajib memberikan pengarahan dan pembinaan dalam hal pembentukan program pendidikan yang menekankan pada kemandirian dan berbasis kewirausahaan.Evaluasi program dilakukan dalam keadaan rapat koordinasi dan konsultasi oleh yayasan.

\section{Implikasi}

Perencanaan pendidikan kemandirian yang berbasis kewirausahaan di Pondok Pesantren Darussyifa Al-Fithroh yang dirapatkan secara dadakan sebaiknya tidak dilakukan sampai larut malam karena akan mempengaruhi kesehatan maupun aktivitas para asatidzh dan karyawan sehingga mengurangi konsentrasi peserta dan membuat suasana rapat menjadi tidak nyaman.

Pelaksanaan pendidikan kemandirian berbasis kewirausahaan di Pondok Pesantren Darussyifa Al-Fitroh dapat digunakan sebagai contoh untuk pesantren yang lainnya. Dengan konsep pemberian suri tauladan dan pembiasaan yang baik, kegiatan ini dapat membangun sikap kemandirian santri tidak hanya dalam bidang kewirausahaan tetapi juga dalam kegiatan pengajian klasikal pertingkat. Selain itu, kegiatan ta'aruf yang diberikan kepada calon santri baru membuat para santri memiliki semangat besar dalam 
melaksanakan kegiatan pendidikan yang mandiri dan berbasis kewirausahaan. Sebagai wujud dari perbaikan program ini diharapkan semua santri ikut serta dalam sistem rolling di setiap minggunya. Agar semua para santri dapat belajar memahami dan melaksankan berbagai kegiatan pendidikan kewirausahaan.Pengawasan program ini dilakukan oleh semua pengelola pesantren demi mewujudkan pelayanan yang baik kepada para santri melalui 5P, yaitu pembinaan, pengayoman, pengasuhan, pengajaran dan pengawasan.Dalam melakukan pengawasan sebaiknya jangan menunggu pihak pimpinan pondok pesantren menyuruh untuk melaksanakan kegiatan pengawasan.

\section{DAFTAR PUSTAKA}

Aliyyah, RR. Penyelenggaraan Pendidikan Berbasis Karakter dan Teknologi Dalam Mengatasi Tantangan Globalisasi. Jurnal Sosial Humaniora ISSN 2087-4928 Volume 5 Nomor 1, April 2014. https://unida.ac.id/ojs/index.php/ISH/a rticle/view/530. Diunduh pada tanggal 8 Desember 2017 pukul 10:12 AM
Antara News. Jumlah Pengangguran 2016 terendah sejak reformasi. Diunduh dari http://www.antaranews.com/berita/591 934/jumlah-pengangguran-2016terendah-sejak-reformasi.

Daradjat. Zakiah. 2012. Ilmu Pendidikan Islam. Bumi Aksara. Jakarta.

Daryanto. 2012. Pendidikan Kewirausahaan. Gava Media. Yogyakarta.

Marzuki. 2015. Pendidikan Karakter Islam. Bumi Aksara. Jakarta.

Michel Huberman. A \& Matthew B. Miles. 1992. Analisis Data Kualitatif. Universitas Indonesia. Jakarta.

Moleong. Lexy J. 2006. Metodologi Penelitian Kualitatif. Remaja Rosdakarya. Bandung.

Muhtadi. Asep Saepul. 2015. Manajemen Komunikasi. Pustaka Setia. Bandung.

Nata. Abuddin. 2003. Kapita Selekta Pendidikan Islam. Angkasa. Bandung.

Sumahamijaya. Suparman. 2003. Pendidikan Karakter Mandiri dan kewiraswastaan, Bandung.

Usman. Husaini. 2013. Manajemen Teori, Praktik, dan Riset Pendidikan. Bumi Aksara. Jakarta. 